April 2002

\title{
12/7 and 9/11: War, Liberties, and the Lessons of History
}

Eric L. Muller

University of North Carolina School of Law

Follow this and additional works at: https://researchrepository.wvu.edu/wvlr

Part of the Civil Rights and Discrimination Commons, and the United States History Commons

\section{Recommended Citation}

Eric L. Muller, 12/7 and 9/11: War, Liberties, and the Lessons of History, 104 W. Va. L. Rev. (2002).

Available at: https://researchrepository.wvu.edu/wvlr/vol104/iss3/7

This Article is brought to you for free and open access by the WVU College of Law at The Research Repository @ WVU. It has been accepted for inclusion in West Virginia Law Review by an authorized editor of The Research Repository@WVU. For more information, please contact ian.harmon@mail.wvu.edu. 


\title{
12/7 AND 9/11: WAR, LIBERTIES, AND THE LESSONS OF HISTORY
}

\author{
Eric L. Muller
}

Since September 11, we have been living in the darkness of two historical shadows. Both are shadows of civil liberties disasters-moments in our nation's history when the balance between domestic freedom and domestic security tipped dangerously away from freedom.

One of them, the more obvious of the two, is a shadow cast by World War II. The images of airplanes crashing into buildings and the pandemonium on the streets of New York took all of us-even those of us who were not alive on December 7, 1941 — back to the panic of that earlier assault on American soil. And as it became clear to us that the terrorists were Arabs, and reports of vigilante violence against people thought to be Arab or Muslim appeared in the news, the shadow of Pearl Harbor's domestic aftermath moved even more fully across the national consciousness. Were we headed for a reenactment of the horrors unleashed on Japanese aliens and American citizens of Japanese ancestry in the wake of the Pearl Harbor attack? For many people, each of the Bush Administration's recent assertions of power-the power to detain or interrogate certain aliens, to monitor certain attorney-client conversations, to run military tribunals, and others - has seemed an ominous lurch into the shadow of the Second World War's excesses.

The other shadow is a bit harder to see. It too is a war-cast shadow, but the war was a cold one. It is what we now call McCarthyism, and its first creeping darkness appeared here in West Virginia, almost exactly fifty-one years ago, 
when Joe McCarthy stood before the Ohio County Republican Women's Club in Wheeling and waved in the air a list of fifty-seven alleged Communists in the U.S. State Department. "The reason why we find ourselves in a position of impotency," the junior senator from Wisconsin said that day, "is not because our ... enemy has sent men to invade our shores, but rather because of the traitorous actions of those who have been treated so well by this Nation."

In early December, our Attorney General lashed out at those who have criticized his post-September-11investigation and enforcement policies, accusing them of "fearmongering," of "pit[ting] Americans against immigrants" and "citizens against non-citizens," and of "scar[ing] peace-loving people with phantoms of lost liberty."2 To criticize the government, said the Attorney General, was to "aid terrorists," to "erode our national unity and diminish our resolve," and to "give ammunition to America's enemies." When criticism is cast as a small step shy of treason, you can be sure that you are walking in the shadow of McCarthyism.

I would like this afternoon to consider with you some of the lessons of this country's World War II experiences with civil liberties, especially those touching on race and ethnicity. We are now just more than five months past the trauma of September 11. The corresponding time sixty years ago-five months after the attack on Pearl Harbor-was the beginning of May of 1942. Think with me for a few moments about the government's domestic record on civil liberties, race, and ethnicity during these two five-month periods. We will see that the differences outweigh the similarities: as troubled as many of us may be by the breadth of the administration's recent assertions of power, the fact is that the excesses of the Roosevelt record in the months after Pearl Harbor eclipse the Bush Administration's actions since September 11.

It is important for us to acknowledge this - to let this fact sink in and steep a bit—before we undertake the more difficult tasks of understanding why it might be so and of deciding how, if at all, that difference ought to influence our thinking about today's debates about interrogation, detention, and ethnic and racial profiling. We might examine the lessons of history and decide that they are just too off-point or ambiguous to guide us in our new war on terrorism. But we also might conclude that the lessons of World War II point us toward a path of moderation between the darkest parts of the shadows cast by that old war and the cold war.

Today, five months after the attacks of September 11, several hundreds of aliens are in federal custody. ${ }^{4}$ Most of them-for all we know, it could be all

1 Senator Joseph McCarthy, Address at the Ohio County Republican Women's Club (February 9, 1950).

2 Sen. Committee on the Judiciary, available at http://www.usdoj.gov/ag/testimony/2001/1206transcriptsenatejudiciarycommittee.htm (December 6, 2001) (Testimony of Attorney General John Ashcroft). 
of them, but the government has not publicized their identities-are citizens of Arab and Muslim countries. They fall into several categories. Some are held on suspicion of violating the immigration laws. Some are held on criminal charges unrelated to terrorism and the events of September 11. Some might still be under detention as "material witnesses." And at least two are held on terrorism-related charges. $^{6}$

The exact number of federal detainees has been tough to determine. The Justice Department released a list of some of the detainees in November, but has since refused to update it or provide other information about those under detention. ${ }^{7}$ The ACLU has sued to force the government to release more information about whom it is holding and for what reasons, ${ }^{8}$ but the government is fighting the lawsuit. Some estimate the total number of people arrested after September 11 at well over one thousand, but we know from press accounts that the government has released some people. ${ }^{9}$ Ultimately, we are left to guess how many aliens from Arab nations are in federal custody five months after September 11. Five hundred might not be too terribly far from the mark.

More than twice that number of Japanese aliens were in federal custody within not five months but three days of the attack on Pearl Harbor. Beginning on the evening of Sunday, December 7, 1941, FBI agents, assisted by local law enforcement, swept through the Japanese communities of the West Coast and arrested aliens they considered "dangerous." 10 By that Wednesday, some 1200 Japanese aliens were in custody, along with about 800 German aliens and a

military campaign in Afghanistan.

5

See 18 U.S.C. $\S 3144$ (2001).

6 The two whose cases have been in the public eye are Zacarias Moussaoui, the alleged "20th hijacker" charged with conspiring to kill Americans in the September 11 attack, and Richard Reid, the so-called "shoe bomber" who was apprehended while allegedly trying to detonate explosives in his shoes on a transatlantic flight. For a time it appeared that there was a third, an Egyptian student named Abdallah Higazy, who was held for thirty-one days after an aviation radio was purportedly found in a hotel room he occupied near the World Trade Center on September 11. Higazy was freed when another person claimed the radio. See Dale Lezon, $A$ Winding Road to Justice, THE Houston Chronicle, Jan. 27, 2002, at 1. I do not count John Walker Lindh, the so-called "American Taliban," who has been charged with terrorism-related offenses, but under vastly different circumstances due to his allegedly taking up arms with the Taliban in Afghanistan.

7 When the Attorney General testified before the Senate Judiciary Committee on December 6,2001 , he explained that the Justice Department was not releasing the names of those held on immigration charges both because federal statutory law forbade it and because the Department did not want the al Qaeda network to know who was under federal detention. See Frank Rich, Confessions of a Traitor, THE N.Y. TIMES, Dec. 8, 2001, at A23.

8 See Rebecca Carr, Groups Sue U.S. to Learn Who's Held in September 11 Probe, THE Atlanta J. AND ConSt., Dec. 6, 2001, at 14A.

9 See Brooke Masters and Patricia Davis, Moussaoui Has Va. Hearing, THE WASHINGTON PosT, Dec. 20, 2001, at A32. 
much smaller number of Italians. ${ }^{11}$ Unlike today's detainees, nearly all of whom we believe are being held on the basis of at least some sort of violation of the criminal or immigration laws, none of these post-Pearl Harbor arrestees of Japanese ancestry had violated any law. They were arrested because the government thought them dangerous, ${ }^{12}$ and the government thought them dangerous for no other reason than that they had been active in their immigrant communities. They were prominent businessmen, leaders of Japanese cultural and civic organizations, Japanese language teachers, judo instructors, and Buddhist priests. ${ }^{13}$

We have heard reports of shameful delays in the release of innocent aliens wrongly swept up in the FBI's post-September 11 dragnet, and there are undoubtedly many people among the hundreds still under detention whose innocence the government has yet to confess or discover. ${ }^{14}$ Sixty years ago, however, the aliens rounded up within days of Pearl Harbor were detained for months before being given any opportunity to contest their incarceration. ${ }^{15}$ And even when they were "released," they were not really freed; those from the West Coast (which is to say nearly all of them) were forbidden to return to their homes, and had no choice but to join their imprisoned wives and children in the government's ten inland "relocation centers."16

Not long after the federal government concluded its most aggressive sweep for aliens after the September 11 attacks, word leaked out about a federal investigative plan that quickly drew criticism and even sporadic resistance. On November 9, Attorney General Ashcroft sent a memorandum to the nation's ninety-four United States Attorneys and to antiterrorism task forces across the country, asking them to interview more than five thousand young aliens about their activities in the United States, their familiarity with terrorist groups, their experience with weapons, and other things of that sort. ${ }^{17}$ None of the five thousand was a suspect, the Justice Department emphasized; the interviews were purely for gathering information about al Qaeda and other foreign-based terrorist organizations. $^{18}$

11

See Commission on Wartime Relocation and Internment of Civilians, Personal JUSTICE DENIED 55 (1997).

12 In the months before Pearl Harbor, the FBI had compiled three lists of potentially dangerous aliens. The lists were labeled "A," "B," and " $C$," in descending order of perceived danger. Louis Fiset describes these so-called "ABC lists" in his wonderful book IMPRISONED APART 2829 (1997).

13

See PeRsonal Justice Denied, supra note 11 , at 54.

14

15

16

17 Tribune, Nov. 15, 2001, at A4.

See FISET, supra note 12 , at $46-51$.

See, e.g., Bart Jones, Terror Probe Detainee Freed, NEwSDAY, Jan. 23, 2002, at A26.

See id. at 75-82; ERIC L. MUller, Free to Die FOR THEIR COUNTRY 19, 71 (2001).

See Interview Guidelines Set for Questioning 5,000 about Links, SAN DIEGO UNION-

18 See Karen Gullo, Investigators Questioning 5,000 Foreigners in U.S.; Colleges Provide

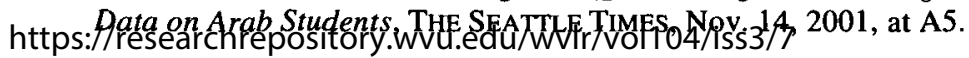


The trouble was that the five thousand men had been selected because they had all come to the United States from countries with suspected terrorist links-mostly Arab and Muslim countries-on student, tourist, or business visas within the two prior years. Almost immediately, the plan was attacked as racial and ethnic profiling. ${ }^{19}$ The government tried to persuade the public that the program was based not on a person's ethnicity per se but on his recent arrival from places where terrorists are known to operate. ${ }^{20}$ The government also emphasized that the interviews were voluntary, and that the interviewees could have a lawyer present if they wished. Many, however, were not persuaded. Arab American community leaders and the ACLU assailed the program as coercive, ${ }^{21}$ and police departments in some parts of the country either criticized the federal policy or refused to help the federal government implement it. ${ }^{22}$

The comparison with Japanese aliens during World War II is, however, instructive. The government undertook a program of interrogating people of Japanese ancestry during that war, but ethnicity was the only factor that determined who was questioned. The questioning took place early in 1943 in the ten permanent relocation centers to which the entire ethnically Japanese population of the West Coast had been moved in the fall of 1942. The government's purpose was to gauge loyalty to the United States rather than knowledge of information that might be helpful in prosecuting the war with Japan, so the analogy to the recent questioning of Arab aliens is admittedly imprecise. But the federal government in 1943 was completely indiscriminate in its targeting. If a person was over eighteen, of Japanese ancestry, and in a relocation center, he or she had to fill out a loyalty questionnaire. ${ }^{23}$ It made no difference whether the internees were aliens or citizens, whether they had ever lived in Japan or held duel citizenship, whether they spoke any Japanese, or even whether they had served with the American armed forces in World War I. All ethnically Japanese people were of equally suspect loyalty in the eyes of the government, and all were questioned.

We might roll our eyes when our government today defends its interrogation program as ethnicity-neutral. After all, while the five thousand young men may not have been selected because they are Arab, we do know that they were selected because they arrived recently from countries where al Qaeda operates, and that certainly sounds like a pretext for anti-Arab discrimination. But

19 See Geralda Miller, Federal Plan to Interview Arab Men Called 'Dangerous', THE GRAND RaPIDS Press, Nov. 21, 2001, at D6.

20

Gullo, supra note 18.

21 See Patricia Hurtado, Cops to Do Immigrant Interviews, NewSDAY (New York), Dec. 6, 2001, at A35; William Glaberson, The Interviews: Legal Experts Question Legality of Questioning, N.Y. TIMES, Nov. 30, 2001, at B6.

22 See Scott Learn, Cities React, Portland Catches the Heat, Portland Oregonian, Dec. 17,2001 , at $\mathrm{Cl}$. 
on closer examination, especially in the comparative light of the interrogation of the ethnically Japanese during World War II, the government's defense of its program is plausible. ${ }^{24}$ The 1990 census counted about 940,000 people of Arab ancestry in the United States, ${ }^{25}$ about eighteen percent of whom were noncitizens. ${ }^{26}$ This made for a total of about 170,000 aliens of Arab ancestry living in the United States in 1990. The numbers in the year 2001 were naturally a good deal higher, although a precise count will not be available until the year 2000 census data are released late in 2002 . Still, 5,000 is just under three percent of 170,000 , a number so small as to suggest that the government did in fact target people for questioning on the basis of criteria other than the raw fact of their origin in an Arab country. The additional criteria that the government announced-age of between eighteen and thirty-three years and recent arrival from a country believed to have been a way-station for members of al Qaedacertainly seem to describe a major subset of those who might have some information, perhaps to them entirely innocent-seeming, that would help the government fend off future al Qaeda attacks.

Most importantly, despite dire predictions that the supposedly information-gathering interviews would be mere pretext for coercive criminal interrogations, this turned out not to be so. ${ }^{27}$ After a somewhat clumsy start, the FBI quickly responded to suggestions and complaints from the Arab American community and ran interviews that lawyers in attendance called "polite, even solicitous." 28 The FBI's New Jersey office invited a prominent lawyer in the Muslim community to give a sensitivity training session to federal agents and local police, and the event was standing-room-only. ${ }^{29}$ In the meantime, the response rate from those the government asked to interview was around ninety percent, and the Attorney General reported when the interviews were through that they had produced "several leads." ${ }^{30}$ Of course, the government now also has a list of those who declined to be interviewed, and it remains to be seen

For purposes of the Equal Protection Clause, of course, the bar of neutrality is not particularly high: discrimination on the basis of pregnancy is, after all, not gender discrimination, see Geduldig v. Aiello, 417 U.S. 484 (1974); and discrimination on the basis of Spanish language ability is not ethnic discrimination, see Hernandez v. New York, 500 U.S. 352 (1991).

25 See Gordon Trowbridge, Arab Americans Lose Out in Census, The Detroit News, March 26, 2001, available at http://detnews.com/2001/census/0103/30/c01-204055.htm. The figure of nearly a million has been criticized as dramatically low; according to a prominent Arab American pollster, the number should have been closer to 3.5 million. See id.

26 See The Arab American Institute, What the 1990 Census Tells Us About Arab Americans, available at http://www.aaiusa.org/arabamericans/census/censustellsus.htm (last visited Feb. 5, 2002).

27 See Niraj Warikoo, Interviews of Arab Men Are Finished, DETROIT FreE Press, Feb. 7, 2002 , at $1 \mathrm{~B}$.

28 Steven Brill, The FBI Gets Religion, NEWSWEEK, Jan. 28, 2002, at 32.

Id. 
what use the government will make of that information. On the whole, though, the program of interrogation, if it was ethnic profiling at all, was ethnic profiling with a decidedly light touch.

It was just that - a light touch - that was conspicuously absent from any of the government's policies toward Japanese aliens and Japanese American citizens sixty years ago. Late in 1941 and early in 1942, the government sent no letters to Japanese aliens and Japanese American citizens inviting them in for interviews. Instead it swept through Japanese population centers in house-tohouse searches, seizing "contraband" such as radios, cameras, binoculars, and even Japanese cultural and religious objects. ${ }^{31}$ Because it was acting under the authority of the Alien Enemy Act of $1798,{ }^{32}$ which authorized the President to order the detention and removal of enemy aliens during a declared war, the government chose to ditch the Fourth Amendment entirely in framing its searchand-seizure program. Gone was the requirement of a warrant from a neutral magistrate. Instead, the administration's regulations allowed a law enforcement agent to get a search warrant not from a judge but from the local United States Attorney, on the basis of nothing more than his unadorned statement that the premises to be searched belonged to an enemy alien. ${ }^{33}$ In cases of claimed urgency, the regulations allowed agents to omit even this sham of an application for an executive warrant. ${ }^{34}$ These might be thought unobjectionable practices for searches of the homes of enemy aliens during wartime, but the trouble was that most of those homes were occupied not just by Japanese aliens but also by their children, all of whom were American citizens and many of whom were teenagers and even young adults in December of 1941. As to these American citizens, the search-and-seizure program was an unadorned and unapologetic violation of the Fourth Amendment.

And for sheer breadth and depth of illegality, those searches in the winter of 1941 and early 1942 did not even begin to compare to the outrages that were in store for American citizens of Japanese ancestry just a few months later. The story, of course, is well known, so I review only its broad contours here. In March of 1942, acting under the authority of President Roosevelt's broadly worded Executive Order 9066, military authorities imposed dusk-to-dawn curfews on American citizens of Japanese ancestry living in a wide swath of territory along the West Coast, and also forbade them from traveling more than five miles from their homes without permission. No such restrictions were imposed on American citizens of German or Italian ancestry anywhere in the United States. Then, in the spring of 1942, the entire ethnically Japanese population of the West Coast, aliens and U.S. citizens alike, were forced from their homes and

31 For further discussion of the government's post-Pearl Harbor raids, see ROGER DANIELS, ASIAN AMERICA 206-08 (1988).

32 See Alien Enemies Act, 1 Stat. 577 (1798) (current version at 50 U.S.C.A. $\$ 21$ (2001)).

33 The text of this regulation is reproduced in DANIELS, supra note 31, at 206.

34 See id. at 207.

Disseminated by The Research Repository @ WVU, 2002 
into grim and overcrowded camps, euphemistically called "assembly centers," that were located at fairgrounds and racetracks in and near the coast's major coastal population centers. Typically, families were given just two weeks to wrap up all of their affairs and report for incarceration, bringing with them only what they could carry. They spent the summer of 1942 in these camps, many of them living in horse stables. They numbered nearly 120,000. Two-thirds were American citizens. ${ }^{35}$

In the fall of 1942, the government transported them by train to the ten more permanent camps that the government had hastily constructed, mostly in barren, desert-like conditions in the Mountain West. The euphemism for these facilities was "relocation centers," but everyone called them concentration camps. They lived with neither comfort nor privacy in tarpaper barracks, surrounded by barbed wire and guarded by U.S. Army sentries in guard towers around the perimeter. After a time, the government made a form of parole available to those in the camps, allowing those who passed their loyalty tests to strike out on their own for points east, so long as they had a place to live and a job, promised not to mix with other Japanese Americans, and could stomach the suspicions and biases of their new Midwestern and eastern neighbors. ${ }^{36}$ Some of the Nisei had the wherewithal to relocate in this way. The majority, however, remained with their alien parents in the camps until 1945, when the war ended and the camps closed. At that point, most returned to the West Coast, where nothing was left of their former lives and they struggled to start over again.

By mid-May of 1942, five months after Pearl Harbor, much of this horror was already underway. Politicians, generals, and newspapermen had been proclaiming the untrustworthiness of any person of Japanese ancestry virtually since the Japanese attack itself. ${ }^{37} \mathrm{~A}$ few, tentative early words from Attorney General Francis Biddle urging tolerance toward Japanese Americans ${ }^{38}$ had long been silenced by the louder voices of racist suspicion. ${ }^{39}$ The dusk-to-dawn curfew and the travel restrictions were already several months old, and the eviction

35 A good and very concise description of these events can be found in RoGER DANIELS, PRISONERS WITHOUT TRIAL (1993).

36 The government's euphemism for this form of parole from the camps was "indefinite leave." A good, albeit rather caustic, description of the leave program can be found in RICHARD DRINNON, KEEPER OF CONCENTRATION CAMPS 52-61 (1987).

37 John L. DeWitt, the commander of the Western Defense Command, put it succinctly in 1942 when he defended his policy of evicting even American citizens of Japanese ancestry from the West Coast with the quip that "a Jap's a Jap." See PERSONAL JusticE DeniED, supra note 11 , at 222 .

38 A few weeks after Pearl Harbor, Biddle urged Americans to remember that "the Bill of Rights protects not only American citizens but all human beings who live on our American soil." See PAGE SMith, Democracy ON TRIAL 99-100 (1995).

39 For example, when Fiorello LaGuardia, the mayor of New York City, called for "decent treatment for enemy aliens" after Pearl Harbor, he mentioned German and Italian aliens but "pointedly omit[ed] mention of the Japanese." See DANIELS, ConCENTRATION CAMPS USA, supra note 10 , at 35 . 
of Japanese Americans from their homes was in full swing. The federal government had already decided to move them from their temporary quarters in the assembly centers to indefinite detention behind barbed wire in concentration camps in the interior. ${ }^{40}$

It seems almost silly to mention it, but in the five months since September 11 we have seen nothing like this. The government has taken no programmatic action against American citizens of Arab ancestry or Muslim faith at all. Indeed, it has done something like the opposite. Just six days after the attacks, President Bush surprised many Arabs and Muslims (and, I might add, me) by appearing at the Islamic Center of Washington, DC, and speaking out forcefully in support of Arab and Muslim Americans. His words were powerful:

America counts millions of Muslims among our citizens, and Muslims make an incredibly valuable contribution to our country. Muslims are doctors, lawyers, law professors, members of the military, entrepreneurs, shopkeepers, moms and dads. And they need to be treated with respect. . . . Moms who [cover their heads] must not be intimidated in America. That's not the America I know. That's not the America I value. . . . Those who feel like they can intimidate our fellow citizens to take out their anger don't represent America, they represent the worst of humankind, and they should be ashamed of that kind of behavior. $^{41}$

The director of the Federal Bureau of Investigation sounded much the same theme that same day, and backed up his words with a promise of action:

Since the horrific attacks on September 11th, dozens of retaliatory hate crimes have been directed at members of the ArabAmerican community. ... I want to make it very clear, vigilante attacks and threats against Arab-Americans will not be tolerated. . . . Such acts of retaliation violate federal law and more particularly run counter to the very principles of the equality and freedom upon which our nation is founded. ${ }^{42}$

"The FBI and the Department of Justice," Director Mueller added, "are committed to aggressively investigating and prosecuting violations of the federal hate

40 For more on how the federal government settled on concentration camps for the ethnically Japanese population of the West Coast, see MULLER, supra note 16, at 31-33.

41 Bush Remarks at Islamic Center of Washington, DC, Sept. 17, 2001, available at http://usinfo.state.gov/topical/pol/terror/01091722.htm (last visited March 11, 2001).

42 Statement of FBI Director Robert Mueller, Sept. 17, 2001, available at http://www.adc.org/terror_attack/Director_Mueller.htm (last visited February 9, 2002). 
crime laws." ${ }^{43}$ And the government followed up these words with action. The Assistant Attorney General for Civil Rights quickly assigned to the Civil Rights Division's National Origin Working Group the responsibility of "help[ing] combat violations of federal civil rights laws affecting individuals perceived to be Arab American, Muslim American, Sikh American, or South-Asian American." ${ }^{44}$ That effort included both education and enforcement efforts, and by February 10 , the Justice Department had opened more than three hundred hatecrime investigations and brought charges in about sixty. ${ }^{45}$

The President and his Justice Department officials were not alone in voicing support for Arab and Muslim Americans in the days after September 11. On September 26, the House and Senate unanimously passed a concurrent resolution declaring that "in the quest to identify, bring to justice, and punish the perpetrators and sponsors of the terrorist attacks on the United States on September 11,2001... the civil rights and civil liberties of all American, including Arab-Americans, American Muslims, and Americans from South Asia, should be protected," and "condemn[ing] any acts of violence or discrimination against any Americans, including Arab-Americans, American Muslims, and Americans from South Asia." ${ }^{, 46}$ Statements condemning ethnic or religious backlash also came quickly from organizations across the social, ${ }^{47}$ economic, ${ }^{48}$ and religious ${ }^{49}$

43

Id.

44 See United States Department of Justice, Civil Rights Division, Civil Rights Division National Origin Working Group Initiative to Combat the Post-9/11 Discriminatory Backlash, available at http://www.usdoj.gov/crt/legalinfo/nordwg_mission.html (last visited February 10, 2002).

45 See Eric Lichtblau, Bias against U.S. Arabs Taking Subtler Forms, L. A. TiMEs, Feb. 10, 2002, at A20. To be sure, Arab and Muslim American organizations say the number of incidents is far higher than the number actually reported. For example, the Council on IslamicAmerican Relations reported the number of anti-Muslim incidents at 1,717 on February 8. See Homepage of the Council on Islamic-American Relations, available at http://www.cair-net.org (last visited February 10, 2002). On the other hand, the Washington Post reported in January that law enforcement was finding it difficult to uncover retaliatory motivation underlying all but one or two of the approximately seven murders that were initially reported as hate crimes. See Alan Cooperman, Sept. 11 Backlash Murders and the State of 'Hate', WASH. Post, Jan. 20, 2002 , at A3.

46 H.R. Con. Res. 227, 107th Cong. (2001).

47 See, e.g., Japanese American Citizens League, JACL Urges Caution in Aftermath of Terrorist Attack, Sept. 12, 2001, available at http://www.jacl.org/current_prs/01091200.htm (last visited April 14, 2002) (statement of leading Japanese American civil rights organization).

48 See Statement by AFL-CIO President John J. Sweeney on September 11 Tragedies, Sept. 12, 2001, available at http://www.aflcio.org/publ/press2001/pr0912.htm (last visited April 14, 2002).

49 See American Jewish Committee Calls on All Americans to Avoid Stereotyping or Scapegoating in Wake of Terror Horrors, Sept. 13, 2001, available at http://www.ajc.org/InTheMedia/PressReleases.asp?did=309 (last visited April 14, 2002); An Open Letter from the Rev. William G. Sinkford, President of the Unitarian Universalist Asso-

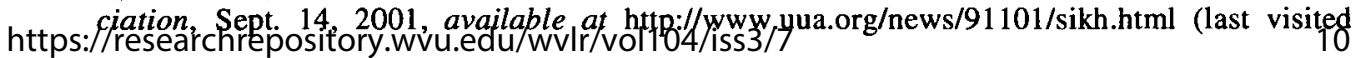


spectrum.

In drawing this comparison between the five months following Pearl Harbor and the five months we have just lived through, I do not mean to dismiss the very real indignities, and in some cases the very real terror and violence, that Arab and Muslim Americans have actually endured. Taunts, scrutiny, and assaults plainly sting and scar, even though they may not match the scale of another people's suffering in a different time. But the fact is that the past five months do not match the scale of the civil rights tragedy that followed Pearl Harbor. We ought to be able to wonder what, if anything, has changed in the last sixty years without worrying that the question itself dishonors the victims of today.

On reflection, we might conclude that nothing has changed-or at least that we are not now in a position to say whether anything has changed. Even quite similar events that occur at different times and in different contexts do not lend themselves to easy comparison. And while the five months after Pearl Harbor and the five months after September 11 are similar in some basic ways, they are also quite different in some basic ways.

Chief among the differences is the course of world events during those two five-month periods. The Bush Administration has enjoyed the luxury of crafting its domestic response to the September 11 attacks with its enemy on the run. In the days immediately after the World Trade Center and Pentagon attacks, the public was deeply afraid of a second wave of attacks, but that wave did not appear. To be sure, there was great public fear in the month of October about what seemed to be a follow-up act of bioterrorism, but within a few weeks, the concerns about anthrax dissipated as it began to become clear that the scare may have been the work of a domestic opportunist rather than al Qaeda. ${ }^{50}$ The American military began its offensive in Afghanistan on October 7, 2001, after diplomatic pressure on the Taliban to surrender Osama bin Laden and his deputies failed. On November 9, just a month later, Mazar-e-Sharif fell. The capital of Kabul followed three days later. Kunduz fell on November 26, and Kandahar on December 6. By December 16, the last of the al Qaeda caves in the mountainous Tora Bora region was in friendly hands. And five days later, an interim government for post-Taliban Afghanistan was sworn in, as many of the top officials of the prior regime remained in hiding or in flight. ${ }^{51}$ Osama bin Laden disappeared from public view entirely amid speculation that he had died or been killed. $^{52}$

April 14, 2002).

50 See Liz Marlantes, "Domestic Loners Top Suspect List in Anthrax Attacks," ChristIAN SCIENCE MONITOR, Nov. 19. 2001, at 2.

51 A timeline of events in the military campaign in Afghanistan can be found at http://www.mapreport.com/countries/afghanistan.html.

52 See Peter Popham, "He May Be Dead, He May Be Trapped," The IndePEndent (LoNDON), Dec. 22, 2001, at 10. 
The contrast with the five months that followed Pearl Harbor could not be starker. The attack in Hawaii was one of a number of coordinated attacks on that day that Japan launched all around the Pacific Rim. Japanese forces attacked in the Phillipines, at Wake Island, Guam, Malaya, Thailand, Shanghai, and Midway. Three days later, they launched an all-out invasion of the Phillipines and overran Guam. On December 11, Japan invaded Burma, and on December 16 and 1.8, British Borneo and Hong Kong. On Christmas Day, the British surrendered at Hong Kong. By the end of January, 1942, the Japanese had invaded the Dutch East Indies, Dutch Borneo, and several of the Solomon Islands. American forces in the Phillipines were isolated in Bataan, and the British had withdrawn to Singapore. By mid-February, Singapore was in Japanese hands. Later that month, Japanese warplanes unleashed a huge assault on Darwin, Australia. On February 23, a Japanese submarine shelled a stretch of beach near an oil refinery close to Santa Barbara, California. By early April, the Japanese were in New Guinea, in Burma's capital of Rangoon, and finally in control of the Phillipines with the American surrender at Bataan. As the five months following Pearl Harbor ended, Japan dominated the Pacific Rim, and had its eye on India, Australia, and the Aleutian Islands off Alaska. ${ }^{53}$

The trauma of September 11 has been intense, and our fears of further acts of terrorism quite real. Our troops have faced real danger in Afghanistan, although happily with little loss of American life. Even so, the political pressures on the Roosevelt Administration in early 1942 must have been extraordinary - and far greater than the pressures to which President Bush and his advisers have had to respond. Had September 11 been but the first in a succession of similar terrorist acts by Arab and Muslim members of al Qaeda, the public might well have demanded more aggressive and invasive investigation of Arab and Muslim aliens in the United States, and even of American citizens of Arab ancestry and Muslim faith. And the Bush Administration's commitment to protecting Arab and Muslim Americans would have been put more powerfully to the test.

A second important difference between 1942 and 2002 is the difference between the targeted minorities. Japanese Americans were not singled out for uniquely illegal treatment during World War II just because the image of the Asian in American culture more easily conjured up images of treachery than the image of the German or the Italian. They were also uniquely isolated and vulnerable in every important way. They were geographically concentrated in a way that German and Italian Americans were not; nearly ninety-five percent of the ethnically Japanese people in the continental United States at the start of World War II lived in a narrow strip along the Pacific, where the perceived danger of a Japanese attack was greatest. Japanese Americans, as a group, were also economically powerless. They were primarily farmers, although some owned or worked in small retail stores and some worked in relatively low-paying service 
industries. There was not a single Japanese American in elective public office. And most of Japanese America lacked the franchise: The immigrant generation, forbidden by law from naturalizing as citizens, remained aliens and could not vote. And most of their children, although born in this country, had not yet turned eighteen by $1942 .^{54}$

More importantly, Japanese Americans were especially attractive targets for mistreatment because they had long been the victims of vicious economic discrimination in the states where they lived. By the 1930s and early 1940s, the Japanese had become very successful farmers up and down the West Coast, often tilling land that had been thought unsuited for commercial agriculture. They were, quite simply, the envy of their white competitors. For years before Pearl Harbor, a combination of white nativists and agricultural competitors had lobbied, often successfully, for laws that would prevent Japanese immigrants from owning land themselves and even from holding it as guardians for their U.S. citizen children. For these interests, the Japanese attack on Pearl Harbor was, in at least one sense, a dream come true: it gave them the opportunity to push for the out-and-out eviction of their Japanese competitors. Nativist groups and the agricultural lobby were among the earliest and most vocal supporters of the exclusion of Japanese Americans from the West Coast. Thus, the eviction and internment of Japanese Americans can really be understood not so much as a military necessity as the capstone of a long campaign of economic discrimination. $^{55}$

Arab and Muslim Americans, by contrast, are happily not so easy or attractive a target. They are dispersed across the American landscape, both geographically and economically. Arab Americans are not concentrated in one narrow region; indeed, to the extent that the Arab American population is concentrated at all, it is in three regions that span the nation-Los Angeles, Detroit, and New York. ${ }^{56}$ Roughly a third of the Arab American population lives in or near those three urban areas, while another third is scattered across seven other states. ${ }^{57}$ Arab and Muslim Americans are also an economically diverse group. A recent poll shows that half of American Muslims earn over $\$ 50,000$ per year, and 58 percent are college graduates. ${ }^{58}$ Arab Americans have a median income that is higher than the national average. ${ }^{59}$ About sixty percent of working Arab

54 For a comprehensive description of Japanese America in the years before the war, see DANIELS, ASIAN AMERICA, supra note 31, at 100-85.

55 For more on the economic rationale for the exclusion of Japanese Americans, see PERSONAL JUSTICE DENIED, supra note 11, at 42-44.

56 Roughly one-third of the nation's Arab population lived in or near these three urban areas, according to the 1990 census. See The Arab American Institute, Arab Americans: Demographics, available at http://www.aaiusa.org/demographics.htm (last visited April 14, 2002).

57 See id.

58 See Virginia Culver, Many American Muslims Well Off, College Educated, Poll Shows, The Denver Post, Jan. 18, 2002, at B3.

$59 \quad$ See 100 Questions and Answers about Arab Americans: Demographics, DETROIT FREE Disseminated by The Research Repository @WVU, 2002 
Americans are business executives, professionals, and office and sales staff. ${ }^{60}$ And finally, Arab Americans claim a number of prominent political leaders among their number, including former U.S. Senate Majority Leader George Mitchell, current Energy Secretary and former U.S. Senator Spencer Abraham, former Secretary of Health and Human Services Donna Shalala, current New Hampshire Governor Jeanne Shaheen, former New Hampshire Governor and White House Chief of Staff John Sununu, and 2000 presidential candidate Ralph Nader. ${ }^{61}$

In short, the post-September 11 world is not the world of late 1941 and early 1942, and the post-September 11 war is not the war of that earlier time. To the extent that some American xenophobes might point the finger at a domestic enemy today, that supposed enemy is far closer to the political, social, and economic mainstream than our supposed enemy of sixty years ago, and in a far better position to protect itself. When we see the restraint in the Bush Administration's policies touching on civil liberties, race, and ethnicity, we may just be seeing the difference that some sturdiness in the suspected minority group and some stability in our sense of security can make.

I would like to speculate, however, that these differences do not fully explain the Administration's policies, and that we may be seeing an important change in the legal landscape as well. What we may be witnessing is the longoverdue death of the Supreme Court's 1944 decision in Korematsu v. United States $^{62}$ and the principle of permitting broad racial assumptions in wartime policymaking that the decision represented. Fred Korematsu was a twenty-twoyear-old American citizen of Japanese descent in May of 1942, living and working as a draftsman in San Leandro, California, when he and his family were ordered to report to the assembly center at the Tanforan racetrack for indefinite incarceration. Korematsu's family did what they were told, like almost all Japanese Americans at the time. But the young man just wanted to go about his business and stay in town with his Italian-American girlfriend. At the end of the month of May, he was arrested and charged with the crime of violating the military's exclusion order. In defense, Korematsu argued that the order was unconstitutional. When he was convicted, he took the case all the way to the United States Supreme Court. ${ }^{63}$

Voting six to three, the Court upheld the exclusion order against Korematsu's due process challenge. ${ }^{64}$ Relying on government allegations that were

PRESS, available at http://www.freep.com/jobspage/arabs/arab4.html (last visited Feb. 11, 2002).

60 See id.

61 See Arab Americans: Dispelling Myths, The Seattle Times, Sept. 16, 2001, at A12.

62323 U.S. 214 (1944).

63 For a detailed account of the background and decision of the Korematsu case, see PETER IRONS, JUSTICE AT WAR 93-99, 151-54, 177-85, $311-41$ (1983). 
later revealed to be knowingly false, ${ }^{65}$ Justice Black insisted that military necessity was the basis for the government's selective program of excluding just Japanese Americans, and not German or Italian Americans. ${ }^{66}$ "To cast this case into outlines of racial prejudice," Justice Black wrote, "without reference to the real military dangers which were presented, merely confuses the issue." ${ }^{\circ 67}$ For the three dissenters, however, the racial selectivity in the military order did not confuse the issue; it was the issue. Justice Murphy put it bluntly: "th[e] exclusion of 'all persons of Japanese ancestry, both alien and non-alien,' from the Pacific Coast area on a plea of military necessity . . . goes over the 'very brink of constitutional power' and falls into the ugly abyss of racism." 68

Justice Jackson, as was his habit, put things rather more gracefully and more memorably. Jackson did not believe himself to be in a position to secondguess the military's assessment that the wholesale exclusion of Japanese, but not Italian or German, Americans was necessary. ${ }^{69}$ For that very reason, he did not think it right or wise for the Court to review the order for conformity with the Constitution. "A military commander may overstep the bounds of constitutionality," Jackson wrote, "and it is an incident."70 But when the Court reviews that decision and approves it, "that passing incident becomes the doctrine of the Constitution." And the danger of that, for Justice Jackson, lay not in the present but in the future. Once approved by the Court in the name of the Constitution, the military order acquires "a generative power of its own, and all that it creates will be in its own image."71 The Court's Korematsu opinion, said Jackson, had "for all time validated the principle of racial discrimination in criminal procedure and of transplanting American citizens." ${ }^{72}$ That principle, Jackson worried, would "lie[ ] about like a loaded weapon ready for the hand of any authority that can bring forward a plausible claim of an urgent need." 73

Perhaps in the government's policies of the last five months, we can discern some evidence that Justice Jackson may have predicted wrongly. The fact is that the Court's opinion in Korematsu has not had the generative power that Justice Jackson feared. It is true that the Korematsu decision has never been

not invoke the Equal Protection Clause because the Court had not yet made it applicable to the federal government. See Bolling v. Sharpe, 349 U.S. 294 (1954).

65 See Korematsu v. United States, 584 F. Supp. 1406, 1417-19 (N.D. Cal. 1984).

66 See Korematsu, 323 U.S. at 223.

67

Id.

Id. at 233 (Murphy, J., dissenting).

Id. at 244-45 (Jackson, J., dissenting).

70

Id. at 246 (Jackson, J., dissenting).

Id.

Id. 
formally overruled, and some worry that this means some on the Court might still see the case as good law. ${ }^{74}$ I think not. First, the main reason that Korematsu has not been overruled is that happily-and contrary to Justice Jackson's prediction-nothing like the facts of Korematsu have arisen in the last sixty years. In order to overrule a precedent, as distinct from merely disapproving it, that precedent must stand squarely in the way of the Court's achieving a desired outcome in a new case. Thus, the Court has not overruled Korematsu primarily because it has not needed to. But more importantly, to the extent that Korematsu stands at all today, it stands as a deeply discredited decision. Eight of the nine currently sitting Justices on the Court have either written or concurred in opinions describing Korematsu as an error ${ }^{75}$-even as spectacular an error as the Court's Dred Scott decision. ${ }^{76}$ It seems safe to say that the majority opinion in Korematsu would not command a single vote today, let alone a majority.

The sixty years that passed between December 7, 1941, and September 11,2001 , were eventful ones in the legal and social development of race and ethnicity in this country. Ten years after Korematsu came the Court's stunning

74 See Dean Masaru Hashimoto, The Legacy of Korematsu v United States: A Dangerous Narrative Retold, 4 UCLA AsIAN PAC. AMER. L. J. 72 (1996); Natsu Taylor Saito, Symbolism under Siege: Japanese American Redress and the 'Racing' of Arab Americans as 'Terrorists,'" 8 Asian L. J. 1, 11 (2001); Alfred C. Yen, Introduction: Praising with Faint Damnation-The Troubling Rehabilitation of Korematsu, 40 B. C. L. REV. 1, 2 (1998).

75 See Stenberg v. Carhart, 530 U.S. 914, 953 (2000) (Scalia, J., dissenting); Adarand Constructors, Inc., v. Peña, 515 U.S. 200, 236 (1995) (O'Connor, J., joined by Rehnquist, C.J., and Kennedy, Scalia, and Thomas, JJ.) ("Korematsu demonstrates vividly that even 'the most rigid scrutiny' can sometimes fail to detect an illegitimate racial classification. . . . Any retreat from the most searching judicial inquiry can only increase the risk of another such error occurring in the future."); id. at 244 (Stevens, J., dissenting, joined by Ginsburg, J.) (referring to the "shameful" and "invidious" burdens that the government imposed on Japanese Americans during World War II, some of which the Court upheld in Korematsu); id. at 275 (Ginsburg, J., dissenting, joined by Breyer, J.) ("[T]he enduring lesson one should draw from Korematsu" is that "scrutiny the Court described as 'most rigid' nonetheless yielded a pass for an odious, gravely injurious racial classification."); Metro Broadcasting v. F.C.C., 497 U.S. 547, 633 (1990) (Kennedy, J., dissenting, joined by Scalia, J.) ("Even strict scrutiny may not have sufficed to invalidate early racebased laws of most doubtful validity, as we learned in Korematsu.").

Chief Justice Rehnquist's condemnation of Korematsu has been the most tepid. In his 1998 book All THE LAws BUT ONE, the Chief Justice defended Koremastu insofar as it upheld the internment of Japanese aliens, and only mutedly criticized the Court for its holding insofar as it upheld the internment of American citizens of Japanese ancestry. See WILliam REHNQUIST, ALL THE LAWS BUT ONE 203-09 (1998). For a critical assessment of Rehnquist's book, see Eric L. Muller, All the Themes but One, 66 U. CHI. L. REV. 1395 (1999).

Only Justice Souter has not condemned Korematsu, and this likely because he has not yet had occasion to do so.

See Stenberg v. Carhart, 530 U.S. at 953 (Scalia, J., dissenting) ("I am optimistic enough to believe that, one day, Stenberg $v$. Carhart will be assigned its rightful place in the history of this Court's jurisprudence beside Korematsu and Dred Scott."). 
and unanimous decision in Brown v. Board of Education. ${ }^{77}$ That, in turn, was followed by decades of effort by the federal courts to implement Brown and dismantle a deeply entrenched system of racial separation and subordination in public education. The political branches joined the effort twenty years after $\mathrm{Ko}$ rematsu with the passage and signing of the 1964 Civil Rights Act, ${ }^{78}$ barring public and private discrimination in a wide variety of settings. The military, which clung to racial segregation during World War II, transformed itself into an integrated institution. The stories of people other than European whites came for the first time into broad public view, in grade school textbooks, on television, and in the movies, and these stories began to weave themselves into the national fabric. And, perhaps most symbolically for our purposes today, Korematsu itself was gutted in the political process when Congress passed and President Reagan signed into law the Civil Liberties Act of $1988 .^{79}$ That Act confirmed the findings of an independent commission that the wartime internment of Japanese Americans had been unjustified by military necessity as well as illegal, ${ }^{80}$ called for the President to issue a formal apology to the surviving internees, and authorized a $\$ 20,000$ token redress payment to each of them.

To be sure, the story of these past sixty years has not been one of relentless progress on racial matters. Deep difficulties remain, and racial and ethnic differences continue to be flashpoints of controversy and even violence in our society. But the restraint in the government's response thus far to the trauma of September 11 might suggest an important change in the legitimacy of racial and ethnic assumptions in our policymaking. The general responsible for ordering the eviction and incarceration of Japanese Americans from the West Coast in 1942 defended his decision with the memorable quip that "a Jap's a Jap." effort at distinguishing citizen from alien, or loyal from disloyal, was, for the general, pointless. His comment caused little outcry, because the public knew what he meant, and most agreed. That is the sort of reasoning, if you wish to call it that, that sixty years of time and change have pushed to the very fringes of legitimate policymaking discourse, or perhaps beyond them. To be sure, the Court's opinion in Korematsu did leave a loaded weapon lying about, as Justice Jackson feared. But the passage of six decades may have emptied much of the ammunition from its chambers.

To some, this may sound like pure Pollyanna. But I have one additional, and I think fairly persuasive, reason to suspect that we might be witnessing a shift in the spectrum of acceptable discourse and policy on race and ethnicity during wartime. Let us look for a moment at the Bush Administration's civil liberties record since September 11 on matters not touching on race and ethnic-

\footnotetext{
$77 \quad 347$ U.S. 483 (1954).

$78 \quad 42$ U.S.C. $\$ \S 1981-2000$ (2002).

79 See 50 App., U.S.C. §§ 1983 et seq. (2002).

80 See PERSONAL Justice DeniED, supra note 11, at 1-18.

$81 \quad$ Id. at 222. 
ity. We quickly see a pattern emerge-a pattern in which the administration has first claimed or requested an extraordinarily broad power, only to narrow its claim or request in response to public reaction and criticism.

The administration's first major domestic policy proposal in the wake of September 11 was its request that Congress significantly expand the powers of federal law enforcement. Within just a few days of the attacks, the Attorney General began to speak publicly about the need for quick reform in federal wiretapping rules and money laundering statutes. ${ }^{82} \mathrm{He}$ focused on the need for "roving wiretaps," which would allow surveillance of an individual wherever he went rather than of a particular phone line.$^{83}$ But by September 19 , when the Administration formally presented legislation to Congress, the proposal had ballooned into an enormous and complex set of new proposals and amendments to a large number of existing federal statutes. ${ }^{84}$ Roving wiretaps were just one of the many proposed changes.

The Attorney General implored Congress to pass the legislation as proposed, and immediately. "The American people," he told the House Judiciary Committee on September 24, "do not have the luxury of unlimited time in erecting the necessary defenses to future terrorist acts. ${ }^{, 86}$ As it happened, though, things moved more slowly than the Administration planned. The same week that the legislation was announced, the ACLU brought together a broad coalition of civil rights and public interest groups to oppose the changes, or at least to urge deliberation and moderation in considering them. ${ }^{87}$ Politicians from the leftsuch as Senator Patrick Leahy of Vermont-and from the libertarian rightsuch as Representative Bob Barr of Georgia-began voicing concerns that things were moving too fast. ${ }^{88}$

It was not until October 26 that the legislation ultimately passed both Houses and was signed by the President-a very speedy process to be sure, es-

See Pete Yost, "Ashcroft Seeks Enhanced Wiretap Powers," AP ONLINE, 2001 WL 27337295 (Sept. 16, 2001).

See Elaine S. Povich, "Ashcroft Seeks Broad Laws," NEwSDAY, Sept. 20, 2001, at A63.

84

See Wayne Washington \& Mary Leonard, "US Seeks New Power to Track, Detain, Deport," The Boston Globe, Sept. 20, 2001, at A31.

85 See Congress Urged to Act Quickly on Anti-Terrorist Legislation, THE PLAIN DEALER, Sept. 18, 2001, at A4.

86 See Elaine S. Povich, Ashcroft: Act Fast on Terrorism; Lawmakers Urged to Pass Statutes, NEwSDAY, Sept. 25, 2001, at A9.

See Nat Hentoff, Getting Back Our Rights, The Village VoICE, Dec. 18, 2001, at 30. Interestingly, the coalition included groups from all over the social and political spectrum, including such disparate organizations as the National Lawyers Guild, the National Council of Churches of Christ, and the Gun Owners of America.

88 For a description of the emergence in Congress of Republican opposition to the USA PATRIOT Act, see Jeffrey Toobin, Crackdown: Should We Be Worried about the New Antiterrorism Legislation?, THE NEW YORKER, November 5, 2001, at 56. 
pecially for such far-reaching changes, but a good deal slower than the passage "by week's end" that John Aschcroft had demanded in mid-September. By the time it passed, the law's title had changed from the relatively innocuous "Mobilizing Against Terrorism Act" to a name with an acronym to make George Orwell proud: the Uniting and Strengthening America by Providing Appropriate Tools Required to Intercept and Obstruct Terrorism Act of 2001, or "USA PATRIOT Act." The law gave the government the roving wiretaps the Attorney General had wanted, but it also gave the government much, much more. Among its provisions were increases in the penalties for a variety of terrorism-related crimes, a new bioterrorism prohibition, search warrants with nationwide effect, and relaxed rules for the monitoring of e-mail messages of suspected terrorists. Two additional and controversial provisions relaxed secrecy rules to allow prosecutors to share grand jury and wiretap information with intelligence agencies, and extended from two to seven days the period for which an alien suspected of involvement with terrorism may be detained for questioning without a criminal or immigration law charge. ${ }^{89}$

This is hardly a package for a civil libertarian to stand up and cheer. But the public criticism and political pressure did temper the bill in a couple of significant ways. The government had asked for a power to detain aliens indefinitely, but got seven days instead. ${ }^{90}$ Congress insisted upon a four-year sunset on the surveillance provisions of the Act, which means that Congress will have to specifically reenact those provisions if it wants to retain them. ${ }^{91}$ In the context of the whole bill, these are admittedly small constraints. But constraints they are, and it is in some sense incredible that any such constraints managed to emerge during the panic of September and early October.

In mid-November, the President announced his executive order authorizing the trial of foreign nationals suspected of membership in al Qaeda in a military tribunal. ${ }^{92}$ This time, the outcry was more intense, possibly because the public's fears had begun to settle a bit with the passage of time and the crumbling of the Taliban in Afghanistan. Lawyers set to debating whether Bush's order was supported by the precedent of the Quirin case ${ }^{93}$ from World War II, in which President Roosevelt ordered trials by military tribunal for Nazi saboteurs who came off of submarines onto the U.S. mainland in New York and Florida. Civil libertarians and some policymakers stressed the inconsistency of defending our free, rights-based society with trials that denied suspects all of the free-

89 For a summary of a very lengthy and convoluted bill, see Adam Clymer, Antiterrorism Bill Passes; U.S. Gets Expanded Powers, THE N.Y. TIMES, Oct. 26, 2001, at A1, B5.

90 See John Lancaster, Anti-Terrorism Bill is Approved, The Washington Post, Oct. 13, 2001, at Al.

91 See Toobin, supra note 88 , at 56.

92 See Military Order: Detention, Treatment, and Trial of Certain Non-Citizens in the War against Terrorism, 66 Fed. Reg. 57833, 2001 WL 1422287 (Nov. 13, 2001).

93 Ex parte Quirin, 317 U.S. 1 (1942).

Disseminated by The Research Repository @ WVU, 2002 
doms we cherish. And initially, the Administration's response was to dig in its heels. Testifying before the Senate Judiciary Committee in early December, the Attorney General asked scornfully, "Are we supposed to read [the al Qaeda captives] the Miranda rights, hire a flamboyant defense lawyer, bring them back to the United States to create a new cable network of Osama TV?"'94

When draft procedures for the military tribunals surfaced several weeks later, however, they were a lot closer to Miranda and a flamboyant defense lawyer than anyone had expected. They contemplated unanimity for the death penalty, a presumption of innocence, proof beyond a reasonable doubt, presumptively public proceedings, a right to appointed counsel, a right against selfincrimination, a right to confront witnesses against them and to present their own witnesses, and a right of appeal to a distinct appellate tribunal..$^{95}$ In short, the draft procedures made the military tribunals look startingly like civilian courts. Crucial differences of course remain, most notably the absence of any sort of impartial reviewing body outside the executive branch. Still, the pattern was noteworthy: a stark assertion of almost infinitely broad power, public scrutiny and protest, and a final move toward moderation.

We have seen the same pattern play out on the issue of the status of captured Taliban fighters. Initially the administration staked out the position that neither Taliban nor al Qaeda fighters captured in Afghanistan were formally entitled to the protections of the Geneva Conventions; it deemed them all "unlawful combatants." Protest from domestic and international human rights groups and some of our European allies followed. Eventually Secretary of State Colin Powell persuaded others in the administration that denying the protection of the Geneva Conventions to Taliban captives would compromise our claim for compliance with those conventions for captured American soldiers overseas. And the President announced a change in policy: while none of the captives was to be given formal prisoner-of-war status, Taliban captives would be entitled to the protections of the Geneva Conventions. ${ }^{96}$

This has been the pattern on government power and civil liberties since September 11: extreme assertion, outraged reaction, and eventual moderation. We can quibble, of course, about whether "moderation" accurately describes the ultimate position the administration has taken in any of these areas. But that is not my purpose in citing these examples. I mention them to point up a contrast with the administration's domestic initiatives touching on race and ethnicity, where, strikingly, we have not seen this pattern. The reason we have not seen it

94 See Zachary Coile, Ashcroft Stands His Ground/Civil liberties focus of Judicial Committee testimony, SAN FRANCISCO CHRONICLE, Dec. 7, 2001, at A17.

95 See Neil A. Lewis, The Military Tribunals: Rules on Tribunal Require Unanimity on Death Penalty, The N.Y. Times, Dec. 28, 2001, at A1; Bush's Rules for Tribunals Taking Shape; Draft Allows Hearsay, Requires Unanimous Vote for Death, THE COMMERCIAL APPEAL (Memphis, Tenn.), Dec. 28, 2001, at A17.

96 See Katharine Q. Seelye, In Shift, Bush Says Geneva Rules Fit Taliban Captives, THE

N.Y. TimES, Feb. 8, 2002, at A1. 
is that in this one area the government has not seen fit to lead with extreme assertions. In the terror and panic of mid-September, the administration might have proposed all manner of restrictions on aliens from Arab and Muslim countries, or even on American citizens of Arab ancestry or Muslim faith. The mind boggles at the possibilites: prohibitions on piloting or traveling on airplanes, bans on crossing bridges or entering skyscrapers, residential curfews, forced relocation or deportation, wholesale detention and interrogation of all aliens from particular nations. Yet none of this happened; in this area the administration has proceeded from a premise of moderation, and has not had to be forced to that position by the pressure of public protest.

Naturally, some have protested the administration's policies anyway, but in context it is the protests and not the policies that can seem extreme. Late in September, for example, James Ridgeway wrote in the Village Voice that "the racial profiling that allows the government to keep tabs on [more than 7 million American Muslims] may be the modern equivalent of a concentration camp." 97 This is an accusation that is doubly unjust: it is unfair to the public officials who have worked hard to avoid anything like a replay of the Japanese American internment, and it is unfair to the tens of thousands of Japanese Americans who came to know through bitter personal experience what it really meant to be locked up in a concentration camp.

In the context of Bush administration's larger enforcement agenda touching on civil liberties, some sort of constraint is operating in the area of race and ethnicity. Undoubtedly international politics provides some of the constraining force. The Bush administration is trying to sustain a broad coalition that includes Arab and Muslim nations, and a domestic enforcement strategy that more aggressively targeted people on the basis of their Arab ancestry or Muslim faith would complicate that effort. ${ }^{98}$ But we might also speculate that coalition maintenance does not fully explain the restraint. Admittedly in fits and starts, this country's judicial, legislative, and executive departments have been pursuing a process of discrediting racial and ethnic assumptions in policymaking since the dark days of the Japanese American internment in World War II. The five months we have just been through allow us to think the hopeful thought that we are far enough along in that process even to weather a national crisis.

Naturally, it is too soon to tell whether these suspicions of progress are real. The shadow of the Japanese American internment is as long as it is dark, and we are still undoubtedly walking in its penumbra. How will we know when we have emerged fully from it, when we are in the free and clear? I doubt we will ever know, and this is ultimately a very good thing because it will keep us vigilant. Justice Jackson put the point nicely in his Korematsu dissent:

98 This would not be the first time in American legal history that international and diplomatic objectives helped form a domestic civil rights agenda. See MARY DUDZIAK, COLD WAR CiviL Rights (2000). 
If the people ever let command of the war power fall into irresponsible and unscrupulous hands, the courts wield no power equal to its restraint. The chief restraint upon those who command the physical forces of the country, in the future as in the past, must be their responsibility to the political judgments of their contemporaries and to the moral judgments of history. ${ }^{99}$

"The moral judgments of history" are, of course, unavailable to us today. Only our children, or perhaps their children, will know for sure how history will judge this country's domestic response to September 11 and the peril of international terrorism. But this does not absolve us of responsibility, because we are George Bush's and John Ashcroft's "contemporaries." If anything is to restrain them, it is our political judgments.

Five months into this war on terrorism, we have some evidence that the system of restraint that Justice Jackson envisioned is working. At several key moments, articulate voices have challenged the government's plans. By and large, the administration has responded constructively. In the healthy light of public scrutiny, something like a middle course has appeared.

At times, however, that course has veered dangerously toward the darkness of McCarthyism. The Attorney General could not have been more deeply and terrifyingly wrong in December when he publicly equated criticism with treason. Criticism is the engine of sound policy, not its enemy. Of course, criticism is not the same thing as reflexive condemnation, and at least as to the administration's policies touching on race and ethnicity, I believe it has earned at least a mild presumption of good faith. Still, Justice Jackson's instruction from sixty years ago must guide our steps today. The path between the shadow of Korematsu and the shadow of McCarthyism is the one identified by Justice Jackson-the path of rigorous scrutiny and robust criticism. 